\title{
EMILY HAHN'S BOEK OVER APHRA BEHN, ROMANTIEK EN FEITEN
}

\author{
DOOR \\ Johanna Felhoen Kraal \\ „Purple Passage”
}

De West-Indische Gids is niet de plaats om de (ongetwijfeld aanwezige) literaire kwaliteiten van Emily HaHN's Purple Passage ${ }^{1}$ ) te beoordelen, noch om de polemiek tussen Clio en Hermes voort te zetten die in de proloog in verzen sprekend ten tonele worden gevoerd. Hierin, en niet minder door de keuze van de titel ${ }^{2}$ ), beslist de schrijfster voor het goede recht van een auteur om in een historische roman ,,fair imagination" tenminste een gedeelte der bladen vol te laten schrijven. En aan eventuele critiek wordt daarmee bij voorbaat de wind uit de zeilen genomen.

Dat de ,lady both famous and fantastic", zoals zij op de omslag wordt genoemd, toch en opnieuw in De West-Indische Gids verschijnt zal de lezers niet verwonderen, zodra zij beseffen dat het om APHRA BEHN gaat.

Deze veel omstreden Engelse roman- en toneelschrijfster uit de zeventiende eeuw heeft reeds vele pennen in beweging gebracht; de Hollandse daarvan niet in de laatste plaats wegens de vraag of zij werkelijk enige tijd in Suriname heeft doorgebracht. Dr H. D. Benjamins en W. R. Menkman hebben zich in een viertal artikelen ${ }^{3}$ ) bezig gehouden met hetgeen uit haar eigen werken

1) Purple passage, Doubleday \& Company, Inc., New York, 1950, 268 pp. (\$3.00). Engelse editie: Aphra Behn, Jonathan Cape, London, $1951(12 / 6)$.

$\left.{ }^{2}\right)$,,Purple passage, also purple patch: A passage conspicuous for brilliancy or effectiveness, in a work that is characteristically dull, commonplace, or uninspired ; often, a piece of obtrusively ornate writing." Webster's new international dictionary of the English language.

${ }^{3}$ ) H. D. Benjamins, Een koninklijke slaaf in Suriname. Roman door 
te putten valt over het leven van APHRA BEHN en met de controversen die daaruit tussen verschillende historici zijn gerezen: haar naam, haar afkomst, de omstandigheden die haar naar Suriname zouden hebben gevoerd, de mogelijkheid dat zij uit eigen ervaring een en ander zou hebben beschreven. Haar novelle Oroonoko, or the royal slave is in vertaling in de eerste jaargang van dit tijdschrift opgenomen ${ }^{1}$ ). De episode uit het leven van Aphra Behn die Emily HaHn in Suriname laat spelen is ook ten dele gebaseerd op de gegevens die Aphra zelf in dit stuk heeft verwerkt.

Maar de hedendaagse schrijfster, als vrouw van haar tijd, is heel wat reëler dan de wel zeer romantische voorgangster en zij heeft van de omstandigheden een voor moderne lezers plausibel verhaal gemaakt. Men kan hierbij de algemene vraag opwerpen in hoeverre het mogelijk is zich te verplaatsen in een geheel andere eeuw en of een auteur niet altijd gedwongen is slechts eigen ervaringen te projecteren in het beeld dat hij van vroeger leven schildert.

Voor Emily HaHn's her-schepping van een leven in een periode van oorlogen, revoluties, verzet, spionnage en contra-spionnage, van een leven bovendien dat veel bewogen is geweest - zowel van plaats als van hart - geldt deze vraag evenzeer. $Z$ ij heeft wijs gedaan niet te insisteren op de technische moeilijkheden van de vele plaats-verwisselingen in APHRA BEHN's leven noch op de puzzles van ,huishoudelijke" aard die deze moeten hebben meegebracht. De gegevens zijn waarschijnlijk ook te schaars geweest en, ondanks de grondige studie van de periode en APHRA's naaste omgeving die de schrijfster heeft gemaakt, houdt haar vie romancée een enigszins gesyncopeerd karakter.

In dit boek begint APHRA AMIs' leven als opstandig en leergierig meisje, met haar moeder en broer, wonend bij oom en tante Johnson in Wye, Kent, royalisten in de na-dagen van

Aphra Behn. Aanteekening betreffende de schrijfster. W. I. Gids jrg. I dl. $I, 1919$, p. 474-476, met portret. Nog eens: Aphra Behn. W. I. Gids jrg. 2, 1921, p. 517-536. Is Aphra Behn in Suriname geweest? W. I. Gids jrg. 8, 1927, p. 451-462. - W. R. Menkman, Suriname in Willoughby's tijd. W. I. Gids jrg. 26, 1944, p. 1-18. Zie ook ,,Suriname van 1651 tot 1668", een hoofdstuk uit JAmes A. Williamson's English colonies in Guiana and on the Amazon, vertaald door NELLy E. VAN Eijck-Benjamins, $W$. I. Gids 8, 1926, p. 1-36, speciaal noot 3 op p. 2.

1) De geschiedenis van den koninklijken slaaf. W. I. Gids jrg. $I$ dl $I$, 1919 p. 477-495; dl 2, 1919 p. 52-70, 1920 p. 339-360, 443-462. 
Cromwell's bewind. Hiermee wordt voor de naam-kwestie, die ook dr Benjamins bezig hield, een aardige oplossing gevonden.

Later in Londen ontmoet zij in het theater William Scot, zoon van Thomas, een der ,regicides". Als William bij de restauratie moet vluchten gaat ApHra mee naar Holland. Zij (of Emily HaHN ?) houdt niet erg van Den Haag, maar zolang Scor in het verzet werkt heeft ze genoeg emoties te beleven.

Nadat Thомas Scoт zich heeft aangemeld en geëxecuteerd is, vertrekken WiLl Scot en Aphra als Mrs Scot naar Suriname. Wij vinden hen terug, met haar moeder, bij aankomst in Torarica, waar APHRA kennis maakt met muskieten en met alle groten van de plaats tijdens het bewind van gouverneur BYAM: JEREMY Pierson, Robert SANDFord, de manager van Lord WilloughBY's plantage Parham: JoHN TREFFRY met zijn negerslaaf CAESAR (= Oroonoko). Zij reizen gezamenlijk de rivier op en de Scots gaan door naar het huis van Sir Robert HarLey: St. John's Hill. Tussen deze plantage - waar zij bezoeken krijgen van o.a. captain MARTIN en DAvid NASSY ${ }^{1}$ ) - en Parham, waar SCOT bij TREFFrY gaat werken, speelt APHRA's Surinaamse leven, waarbij CAESAR steeds een rol heeft als boodschapper en vertrouwde ${ }^{2}$ ). Totdat hij met alle plantage-slaven wegloopt, achterhaald wordt door BYAM en een inderhaast opgeroepen ",militia" waar Scot zich bij voegt.

De ,purple patch” komt hier nog eens in andere woordspeling naar voren, wanneer Scot in het gevecht met de weglopers een zweepstriem over het voorhoofd oploopt.

De beschrijving van deze hele episode en de gruwelijke executie van CAESAR is grotendeels overeenkomstig APHRA BEHN's eigen

1) "who had crossed the forest into the colony from Brazil" zegt Emily Hahn over David Nassy (p. 105). Hoewel het, volgens de heer Menkman, niet geheel onmogelijk lijkt, is het niet gelukt in het Essai historique of bij OPPENHEIM enige aanwijzing te vinden dat kolonisten die Brazilië verlieten toen de Portugezen dit op de Hollanders heroverden, over land naar Suriname zijn gegaan. Van David NASSY zelf zegt het Essai historique (Beschrijvinge, p. 40) ,,Het was in deezen tijd [nl. na 1644], dat David Nassy, zijne Familie en deelgenooten, reeds gewend aan het klimaat van Brazil en den vermoeienden Landbouw, het besluit namen, zich opnieuw in Amerika neder te zetten".

DAvid NASSY kreeg in 1659 van de West Indische Compagnie een patroonschap voor het eiland Cayenne ,,ofte andere Plaatsen aan de wilde Kust van West-Indiën..." (Beschrijvinge deel 2, p. 93).

$\left.{ }^{2}\right)$ Hierbij kan worden opgemerkt hoezeer ook Albert Helman in De stille plantage de rol van de hoofdslaaf op gelijksoortige wijze psychologisch heeft verwerkt. 
relaas in het verhaal van Oroonoko. En het is goed dat wij ons nogmaals de merkwaardigheid realiseren van een schrijfster in de zeventiende eeuw, die de onmenselijkheden van de slavernij als zodanig ziet en de woordbreuk van de blanken tegenover de achtervolgde slaven aan de kaak stelt. Maar ook hier heeft Emily HAHN de omstandigheden en het tussenspel voor de hedendaagse lezer psychologisch aannemelijk gemaakt. Zo wordt APHRA's weigering om, na deze ervaringen, bij Scot te blijven verklaarbaar en daarmee haar huwelijk met BEHN, een Hollander die tijdelijk in Torarica vertoeft. Zeer menselijk ook en begrijpelijk, hoe APHRA BEHN tenslotte toch weer met Scot wegloopt wanneer deze opnieuw om zijn schulden moet vluchten en naar Europa teruggaat.

De scène verlegt zich nogmaals naar Holland, waar nu de bannelingen, als vóór hen de royalisten, ,gevestigden" zijn geworden, met Hollandse vrouwen getrouwd. Weer toont APHRA zich niet thuis te voelen in ons kille klimaat en, zodra er een kans is, gaat zij naar Londen, om haar hart op te halen aan toneel en voor William Scot's gratie te pleiten. Hier komt zij in aanraking met vele beroemdheden van de theaterwereld: NAN MARShall aan wie zij een Indiaanse verentooi uit Suriname geeft (cf. Oroonoko p. 478); JoHn Hoyle, Tom Killigrew.

De mogelijkheid van gratie voor Scot wordt min of meer afhankelijk van zijn diensten als contra-spion en APHRA zelf krijgt een opdracht om in Antwerpen de Engelse secret service te helpen. Zij slaagt hierin niet, ook niet in samenwerking met Scot die kort daarop in Holland voor schulden gevangen wordt gezet. Pas als het haar gelukt is hem vrij te krijgen, is zij ook definitief bevrijd van haar gebondenheid aan ScoT.

En dan terug in Londen en zelf niet in staat haar schulden te betalen - de gevraagde vergoeding voor de Antwerpse diensten blijven uit - vindt zij op het kritieke moment een nieuwe lover in John Hoyle. In de wereld van het theater leeft zif verder en de lezer eindigt met de emoties bij de eerste opvoering van APHRA BEHN's toneelstuk The forced marriage.

Alleen in de epiloog, die het opschrift citeert van de steen waaronder APHRA BEHN in de Poets' Corner van Westminster Abbey begraven ligt, wordt een jaartal genoemd (1689). Met de vermelding van CROMWELL en de restauratie, de toespelingen op de oorlogen tussen Engeland en de Republiek in de roman zelf, is dit de enige indicatie voor een argeloze lezer, die nooit van APHRA BehN heeft gehoord, van de tijd waarin haar leven 
zich afspeelde. Een groter detailkennis van de Engelse geschiedenis dan men van Nederlanders in het algemeen kan verwachten wordt verondersteld, maar de kleurige milieuschildering en de knappe techniek van EMILY HAHN maken het boek ook voor niet historisch geschoolden zeer leesbaar.

Het is zeker niet haar schuld dat ApHra BeHN in de Engelse letterkunde meer bekendheid geniet dan in Holland en de handschoen, die zij Nederlandse onderzoekers toewerpt om in de Hollandse West-Indische archieven te delven naar nadere gegevens, moge bij gelegenheid worden opgeraapt.

Hoe dit zij of worde, de huidige biografe is er in geslaagd een levend portret te tekenen van een vrouw die een voorloopster is geweest in de strijd voor onafhankelijkheid van vrouwen en slaven beide, terwijl zij zelf in haar werk het voorbeeld heeft gegeven van een gelukkige ,fforced marriage” tussen de muze der historie en Hermes, ,,god of rogues and liars".

\section{FEITEN EN VRAagtekenS}

Ziehier wat EmIL y HaHn zo vriendelijk was uit Engeland te schrijven, op mijn vraag iets te willen mededelen over de gegevens waarop zij haar roman heeft gebaseerd.

Nothing new about the Englishwoman ApHra BeHN (1640-1689) has been discovered for many years. Because she was (perhaps) married to a Dutchman, the interested English or American scholar feels, admittedly unreasonably, that nothing fresh is likely to be discovered on this side of the Channel, and that it is up to Holland to carry on the search. Yet more, perhaps, has been done in Holland than here. Dutch scholars are at home with the English language, whereas few English people can read Dutch, and those who work on this problem in Holland can claim to know as much as we do, and probably more than we do, about the few scraps of information that have been dredged up in British history. Such scholars will be interested in the paper published by an American, Harrison Gray Platt Jr., in the Publications of the Modern Language Association, Number 49, for 1934. Mr. Platt wrote this article as a doctor's thesis for the John Carter Brown University, where the library has a good collection of North American maps of the seventeenth century, including those of the West Indies $\left.{ }^{1}\right)$. Because I used his theory as a skeleton for my novel, I shall refer to this paper in detail.

True primary source-material is scarce. We cannot accept as gospel , Mrs. BEHN's alleged autobiographical data which occurs in her best-

1) Zie de bij dit artikel gereproduceerde kaart. 
known work, the novelette Oroonoko. Some of the details probably bear a certain relation to the truth, but that is as far as it is safe to go. For hard and fast material there are the letters written from Antwerp, and a few evidently written in London; these are in the Calendar of State Papers. The anonymous biography published seven years after her death is vague.

It is fairly certain, however, that APHRA BEHN was born at Wye, and that her family name is Amis. Dr Benjamins maintains that the only indication that the ApHra BeHn of the plays was ApHra Amis, baptized at Wye, is the similarity of the Christian name ${ }^{1}$ ). However, Gosse discovered a note made by Anne, Countess of WinchelseA, in the margin of a book of POPE, stating that Mrs. BEHN was the daughter of a barber at Wye, near Canterbury. It is easier to accept APHRA Amis as ApHra BeHn than to presume two coincidences; that there were two girl babies of the same age named APHRA, and that both were born at Wye.

Perhaps, as I have said, Aphra Amis married a man from Holland whose name was BEHN. Her biographer says so, and there is no other explanation given by contemporaries of her acquisition of the name, but there is absolutely nothing known about this man. Her connection with Holland, as far as we know, consisted of the work she did for the Intelligence service under Charles II, when she went to Antwerp and sent back reports based on information supplied by a man named WILLIAM Scoт. In these reports she called herself Astrea, and Scor was known as Celadon.

Platt's theory, very briefly, is this: Aphra ran away from England with Sсот, at the time of the Restoration, when she was twenty. (Scor was the son of a regicide - this is not theory, but fact - and had worked during the Interregnum as an intelligence agent under THURLOE. He was evidently often in debt.) The lovers went to Surinam, which at the time served as refuge for Commonwealth fugitives, just as it had been a refuge for Cavaliers.

There is no mention of APHRA nor of Scot by their own names in Surinam records, but PLATT refers to a letter from one of the officials there, in the Willoughby papers, about ,Astrea and Celadon" and how they left the colony in 1663/4 (West Indies and Guiana, I623-1667, Hakluyt Society, Series 2, Vol. 51, p. 191).

Mr. Platt retorts to the Bernbaum articles ${ }^{2}$ ) that Aphra's obvious cribs from George WARREn's Impartial description of Surinam need not indicate that she herself was never there, as it would be only natural that she would wish to refresh her memory after an absence of twenty years. Her greatest distortion, he thinks, is that she claimed to have gone to Surinam as the daughter of a deputy governor, rather than as a fugitive's mistress.

In my novel I have taken many liberties wherever I came across a blank in the facts as we know them, and there is more blank than fact in the life of Aphra Behn. I used Mr. Platt's theory, and where this

1) Zie W. I. Gids 8, 1927, p. 456, 2e alinea.

2) Deze worden uitvoerig besproken in de hiervoor genoemde artikelen van Benjamins. 
fell short I improvised, concentrating on what I could learn of Surinam and the slaves there. I found Melville Herskovits' Suriname folklore suggestive and helpful, though it is about modern Bush Negroes. STEDMAN's Voyages, though it is of a period a century after APHRA's life, also helped. Material on the slave-trade is to be found in SAmUEL OpPenherm's An early Jewish colony in Western Guiana, 1658-1666.

Readers of Oroonoko will no doubt recall the significant trivialities of the Negro hero's vocabulary. Mrs. BEHN says that he called white people „Backearary”. To this day Negroes in the southern States of America, and in Jamaica and other West Indian regions, refer to white people as ,Buckra”. Oroonoko called children ,,picaninnies” as Negroes in the Western world still do. He claimed to be a King; so do many transplanted African Negroes even today. Professor BERn Baum to the contrary notwithstanding, I am sure that Mrs. BEHN talked at length with some African slave in Surinam.

Who was BeHn? There seems to be no trace. There are BeHns in the United States, and they believe themselves to be of Dutch extraction. One family (which incidentally claims to be descended from APHRA BEHN, though they have no proof or firm tradition for this belief) came to the States from St. Thomas in the Virgin Islands. May ApHra possibly have met BEHN in Surinam? Long before the colony became Dutch, many Dutchmen traded and visited there. Did she bear a child in the West Indies? Or did she meet BEHN in England or in Holland? The answer may lie in Dutch colonial archives.

\section{EEN ENGELSE KAART VAN SURINAME UIT 1667}

Een fotocopie van de kaart van Suriname, die Emily HahN eveneens heeft gebruikt als materiaal voor haar roman Purple Passage heeft de schrijfster welwillend ter beschikking gesteld van De West-Indische Gids. Het origineel berust in de John Carter Brown Library te Providence, Rhode Island, welke bij monde van dr LAWRENCE C. WROTH toestemming voor de reproductie verleende. Een andere fotocopie bevindt zich thans in het Algemeen Rijksarchief te 's-Gravenhage.

Om technische redenen was het nodig de foto voor de reproductie over te tekenen. Hierbij moesten de in het origineel geschreven namen van de plantages en de bijschriften worden weggelaten daar zij bij de verkleining onleesbaar zouden zijn. De namen der plantages werden vervangen door nummers, die corresponderen met bijgaande lijst; men lette er op dat de figuren die de plantagehuizen aanduiden van verschillende grootte en soort zijn. De nummers zijn zoveel mogelijk ,,riviersgewijze" aangebracht, hoewel niet geheel consequent volgens het systeem van rechter en linker oever. De namen van andere aanduidingen zijn door letters vervangen. De bijschriften volgen hier. 
Naast de passer, bovenaan rechts staat:

A discription of the Coleny of Surranam in Guiana

Drawne in the yeare 1667

the planters names as they are settled in their

Plantations in the Severall parts of the Cuntry: the land is low and very full of woods: its very Bad Travelling from one Plantation to an other without Boats.

Onderaan links is te lezen:

Thes figers singnifie the fathams of water; the Rivers mouth Lys in the Latt. of five degres \& feivety minuts north: the tid Ebbs and flowes Eight foot and keeps its Course and Runs as Strong as at Graves End: it is at High water on the Chang[e] day of the mone: at fower of the Clocke: in the Rivers mouth The winds Blowes at East generally in the day times a stronge Gale. It Raines much in ye months of November, decembr January \& February/March \& Aprill \& May \& June ar dry: July \& August Raine much: September \& october ar dry.

De kaart is met de hand getekend; dit zou er op kunnen wijzen dat we met een unicum te maken hebben, terwijl het jaartal 1667 mogelijk een indicatie is van vervaardiging ten behoeve van de overdracht van Suriname aan de Hollanders. Op mijn vraag of er in verband met het origineel aanwijzingen hierover te vinden zijn, antwoordde dr WROTH het volgende:

„This map came to the John Carter Brown Library as one element in a great mass of business papers, charts, and other materials arising from the mercantile operations of the Brown family of Providence for the past two hundred years. From relatively early in the eighteenth century through the period of the American Revolution the Browns were engaged in the Surinam trade".

„The map is drawn, colored, and lettered by hand upon a sheet of vellum of irregular size ${ }^{1}$ ). The map does not seem to me to have any political implications, though the coincidence of its date, 1667, with the date of the Treaty of Breda seems to suggest that it was made with the current discussion in view. It could have been done for the information of the Lords of Trade or some other committee concerned with colonial matters or with the negotiation of the treaty. On the other hand, it has the appearance of a good many maps of the period drawn for the information of mariners and of those trading to the colonies. The marking of the fathoms and of the channel entering the Surinam River and the location of the various English plantations throughout the colony seem to suggest that purpose behind the map". 
Ter vergelijking met de thans gereproduceerde kaart van 1667 moge gewezen worden op een gedeelte van een kaart uit 1671 dat zich in de collectie van het Algemeen Rijksarchief bevond. Het origineel is verbrand op de Parijse tentoonstelling 1931. Achter op de foto-copie aanwezig in de Centrale Boekerij van het Koninklijk Instituut voor de Tropen (nr. Suriname 729) staat getypt: ,Caerte ofte Vertooninge van de Rivieren van Suriname en Commewijne met verscheyde creken uyt deselve spruytende, als Para, Surinoo en Cottica ende ander meer, gelijck die nu tegenwoordich bewoont werden. Anno 1671. Algemeen Rijksarchief nr. 1666".

Dit stuk toont enkele der zelfde namen van plantageeigenaren als op de kaart van 1667; bij sommige staat de oude naam en daarachter: nu...

Op deze kaart (foto) van 1671 staat Joodse Sijnagogn ongeveer op de plek waar de Engelse een dubbel huis tekent met het bijschrift ,.Jews". Volgens het Essai historique is een kleine synagoge in 1672 gebouwd (de grote op een andere plaats in 1685). Oudschans Dentz, De kolonisatie van de Portugeesch Joodsche natie in Suriname en de geschiedenis van de Joden-Savanne, Amsterdam 1927, p. 13, wees er reeds op dat de eerste synagoge gebouwd moet zijn tussen 1665 en 1671.

Voorts zijn voor vergelijking van belang de kaart uit 1686 gereproduceerd bij het artikel van KNAPPERT, ,, De Labadisten in Suriname” (W.I. Gids 8, 1926, tegenover p. 208) en de kaart in Herlein, Beschrijvinge van de volk-plantinge Zuriname, Leeuwarden, 1718, tegenover p. 1, door A. MAars vervaardigd.

Men lette er op dat Braamspunt op de kaart van 1667 Byams pointe heet ${ }^{2}$ ), kennelijk naar de Engelse gouverneur die van 1654 tot de overgave in de kolonie van Willoughby het bewind voerde. Het Essai historique (in vertaling: Geschiedenis der kolonie van Suriname, 1791, p. 47) vermeldt dat deze plek Parhams-Punt of Kaap Willoughby van Parham werd genoemd, ,waarvan men daarna, door verbasteringe, heeft gemakt Bramspunt"'. Het gedeelte van de kaart van 1671 mist de kust en de riviermond. Op de kaart in Herlein komt Brams Punt voor, op die van DE LAVAUX is geen naam vermeld bij deze plek.

In Cullureel Indië 1946 p. 43 verscheen een artikel van FRED. OUdSCHANS DENTZ ,,Capitulatie en bevrijding van Suriname in de 17de, 18de en 19de eeuw". Hierin komt als afb. 4 een reproductie voor van een gezicht op Braamspunt, vlak boven de beschrijving van het eskader van vice-admiraal VAN BRAAM dat eind 1815 naar Suriname voer in verband met de overneming van het gezag door de Nederlanders van de Engelsen. De door de auteur waarschijnlijk ongewilde suggestie die van deze ,opmaak" uitgaat, als zou Braamspunt naar VAN BRAAM heten, wordt voldoende ontzenuwd door de oude kaarten.

Een ander voorbeeld van naamsverbastering vinden we op deze kaarten ten opzichte van de Mott-kreek. Bij de Engelsen heet deze in 1667 Mud-Creeke; de Labadisten noemen hem in 1686 Mott-cr.; HERLEIN (MAARS) zet bij het water Cottera Stroom en bij een huis aan de oever Mot.

1) Volgens de foto heeft het origineel een trapezium-vorm, waarvan de basis ongeveer $60 \mathrm{~cm}$ breed is en de hoogte $\pm 63,5 \mathrm{~cm}\left(23^{3} / 4 \times 25\right.$ inch)

$\left.{ }^{2}\right)$ Zie Purple passage, p. 83 


\section{o Penemica \\ $\mathrm{x}$ Leekes \\ 1 Tom Apatibo \\ 2 Merimato \\ 3 Meruimo \\ 4 Orutobere \\ 5 Hunter}

6 Read

Brecton Creeke

7 Oxenbrigh

8 Rimo

9 Lerms

10 Amatembo

11 Oronomobbo

12 Comerilho

$13 \mathrm{Ja}[\mathrm{bo}]$ (?)

14 Armatam = (bo?)

15 Supemica

16 Inica

17 Pucabetre

18 Putaga

19 Tabeta

20 Tobago

21 Ponama

22 Opegetanda

23 Egerton

24 House

a Monereca

25 Cuit

26 Price

27 Newington

28 Bride

29 Hollis

30 Marawaribo Indian Towne

31 Indians Yambo

32 Laila

33 Windall

34 Pramarico Indians

35 Packawara

36 Onaracabe

37 Japea

38-104 LtGen. Byam

39 Otapei

40 Waaperre

41 Bruning

42 Hutton

43 Finch

44 Allen

45 Sergeant
46 Stark

47 Smith

48 Wembleton

49 Forrest

b Funck Tree

50 Otuma

51 Pacomca (?)

52 Cowaco

53 Carchebo

54-61 Westrope

55 Symmons

56 Hart

57 Curtis

58 Williams

59 Maxwell

60 Straunge

61 zie 54

62 Titus

63 Vrpith

c Houghton hill

64 Burdon - Gewanon (?)

65 Render

d Armadille hill

e Kirton Creeke

66 Delaware

67 Scotsmen

68 Colison

69 Raudon

70 Limbry

71 Story

72 Lambert

73 Slade

77 Perry

75 Sanford Sr. Rob. Harley

76 Mushart

77 Lee

78 Adamson

79 Smith

80 Gaudre

81 Manton and Norris

82 Dodd

83 English

84 Parrham hill

85 Hargrove

86 Hargrove

87 Scattergood

88 Minnicks

89 Rous
90 Masey

91 Carpenter

92 Minnicks

93 Clerke

94 Nasserer

95 Gavy

96 Desijlra (sic

f Black Creeke

97 Ely

98 Jews

99 Fines

100 D. Casseres

101 Nunes

102 Chace

103 Griffin

104 zie 38

105 Peirson

106 Browne

107 Hibbart

108 Defanseca

109 Millard

110 Mesa

111 Pereira

112 Peirson

113 Thurston

114 Holland

115 Bligh

116 Kingsland

117 Region

118

119 Toorarica

120 the towne

121

122 Stantor

123 Ropamica

124 Eggron

125 Washington

126

127 Parker

128 Cumingha

129 Clayton

130 Watkins

131 Dullen

132 Fennell

g Red Rock

133 Lark

134 Creeke

135 Leech

136 Gray

137 Colvill

138 Banister 


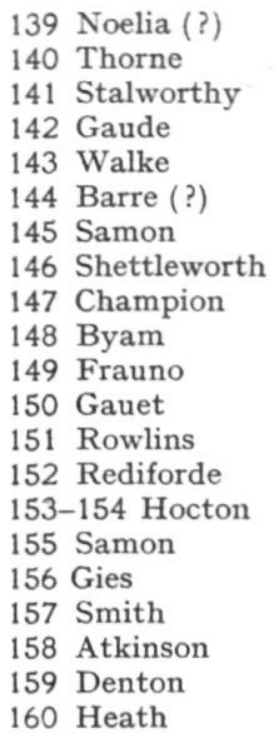

$\begin{aligned} & 161 \text { Hunt } \\ & 162 \text { Martin } \\ & 163 \text { Pilgrim } \\ & 164 \text { Humphries } \\ & 165 \text { Elsing } \\ & 166 \text { Darnell } \\ & 167 \text { Wason } \\ & 168 \text { Davies } \\ & 169 \text { Noelia wharfe } \\ & 170 \text { Bruming } \\ & 171 \text { Render } \\ & 172 \text { Wyatt } \\ & \text { h ye Fort } \\ & 173 \text { Ranier } \\ & 174 \text { Whood } \\ & 175 \text { Clark } \\ & 176 \text { Hootiman } \\ & \text { i Tygers hoole } \\ & 177 \text { Blank } \\ & 178 \text { - Red Bancke } \\ & \text { j } \text { Red }\end{aligned}$

161 Hunt

164 Humphries

165 Elsing

66 Darnel

169 Noelia wharfe

170 Bruming

171 Render

72 Wyatt

h ye Fort

73 Ranier

74 Whood

75 Clark

6 Hootiman

77 Blank

j Red Bancke k Flatts

$1 \mathrm{y}^{\mathrm{e}}$ Windward

$\mathrm{m}$ ancle Chanell

n Brakers

o $y^{\mathrm{e}}$ medle Ground

p Leward Channell

q Leward bay

$r$ Devels point

s Il. p.(?)

$t$ The sea coast is all drownded land noe Goeing ashore Bewe ỹ River of Sarranam and ỹ River of Surramica

u The Sea Coast to windward of Surrinam River

\section{SUMMARY}

The well-known American author Emily Hahn (= Mrs. Charles BOXER) has written a biographical novel on the equally famous seventeenth century English playwright APHRA BEHN. The few facts known about the life of APHRA BEHN and, especially the question whether her short story Oroonoko, or the royal slave may possibly have been based on personal experience in Surinam, have given rise to many controversies. Dutch historians (Benjamins and Menkman) have written on this subject in De West-Indische Gids (see note 3 on p. 143).

After a short survey of the contents of Miss HAHN's novel her own remarks on the material she used are published (p. 147-149). A 1667 map of Surinam which Miss HAHN equally used is reproduced with the consent of the John Carter Brown Library, Providence, Rhode Island. For details about the original map see p. 150. The plantation names and other inscriptions have been transcribed in the list on p. 152-153. 